\title{
PENGARUH PENDAPATAN PERKAPITA TERHADAP PERMINTAAN KEBUTUHAN POKOK MASYARAKAT DI KECAMATAN WARA SELATAN KOTA PALOPO
}

\author{
Muh. Yususf $\mathbf{Q}^{1}$, Haedar $^{2}$, Estik $^{3}$ \\ 1) Dosen Sekolah Tinggi Ilmu Ekonomi Muhammadiyah Palopo \\ ${ }^{2,3)}$ Dosen Sekolah Tinggi Ilmu Ekonomi Muhammadiyah Palopo
}

\begin{abstract}
Abstrak: Tujuan penelitian ini adalah untuk mengetahui dan menganalisis pengaruh pendapatan perkapita terhadap permintaan kebutuhan pokok masyarakat di Kecamatan Wara Selatan kota Palopo.

Jenis Data yang digunakan yaitu diperoleh dari BPS Kota Palopo berupa Data sekunder berbentuk time series dari tahun 2011 sampai dengan 2015. Metode analisis Data yang dipergunakan dalam penelitian ini adalah analisis deskriptif dan Regresi Sederhana, dimana variabel bebasnya yaitu pendapatan perkapita sedangkan untuk variabel dependen yaitu permintaan kebutuhan pokok. Hasil penelitian ini pendapatan perkapita berpengaruh positif signifikan terhadap permintaan kebutuhan pokok di Kecamatan Wara Selatan Kota Palopo dengan nilai signifikan sebesar 0,036.
\end{abstract}

Kata Kunci: Pendapatan Perkapita dan Permintaan Kebutuhan Pokok.

\section{PENDAHULUAN}

Pendapatan perkapita sering kali digunakan sebagai indikator pembangunan selain membedakan tingkat kemajuan ekonomi antara Negara-negara maju dengan Negara sedang berkembang. Dengan kata lain, pendapatan perkapita selain bisa memberikan gambaran tentang laju pertumbuhan kesejahteraan masyarakat diberbagai negara juga dapat menggambarkan perubahan corak perbedaan tingkat kesejahteraan masyarakat yang sudah terjadi di antara masyarakat yang ada di Kecamatan Wara Selatan Kota Palopo.

Namun demikian, kita harus hati-hati dalam menggunakan pendapatan perkapita itu sebagai suatu indikator pembangunan. Hal ini disebabkan oleh adanya pendapat yang mengatakan pembangunan itu bukan hanya sekedar meningkatkan pendapatan riil saja, tetapi kenaikan tersebut harus berkesinambungan dan mantap serta harus di sertai pula oleh perubahan-perubahan, sikap-sikap dan kebiasan-kebiasaan sosial yang sebelumnya menghambat kemajuan-kemajuan ekonomi.

Tetapi apapun kelemahan pendapatan perkapita sebagai indikator pembangunan, pendekatan ini masih sangat cocok untuk digunakan dan mudah untuk dipahami, dan mungkin pendapatan perkapita adalah indikator pembangunan satu-satunya yang terbaik yang ada saat ini. Pendekatan ini juga mempunyai suatu kelebihan, dimana ia menfokuskan pada raison d'etre dari pembangunan, yaitu kenaikan tingkat hidup dan menghilangkan kemiskinan. Dengan kata lain, pendapatan perkapita bukanlah suatu prokxi yang buruk dari struktur sosial dan ekonomi masyarakat.

Akhirnya dapatlah disimpulkan bahwa pendapatan perkapita masih tetap bisa digunakan sebagai suatu titik awal untuk mengklasifikasikan tingkat-tingkat pembangunan, dan sudah tentu pula bisa digunakan untuk mengidentifikasikan kebutuhan pembangunan. 
Meningkatkan pendapatan perkapita masyarakat mendorong meningkatkan pula daya beli masyarakat terhadap barang-barang dan jasajasa terutamanya terhadap kebutuhan pokok manusia antara lain sandang dan pangan serta tanah/bumi dan bangunan. Sebagian besar budaya masyarakat di Kecamatan Wara Selatan Kota Palopo ditunjangkan dengan kepemilikian harta/aset keluarga yang ditandai dengan mempunyai aset berupa banyaknya penguasaan terhadap tanah atau bumi dan rumah atau bangunan.

Peningkatan terhadap pendapatan seharusnya berbanding lurus dengan peningkatan penerimaan masyarakat dari pajak penghasilan, pajak pertambahan nilai, pajak penjualan atas barang mewah dan tak kalah pentingnya adalah pajak bumi dan bangunan. Pertambahan penduduk di Kecamatan Wara Selatan Kota Palopo yang sangat signifikasi menunjukkan pula peningkatan terhadap kepemilikan perluas/bumi termasuk pula tumbuhannya perumahan baik dari tipe kecil, menegah, dan mewah.

Naik turunnya pendapatan nasional perkapita yang ada di masyarakat pasti mempunyai pengaruh dalam berbagai sektor perekonomian dalam suatu masyarakat, pendapatan perkapita bisa menunjukan apakah masyarakat di Kecamatan Wara Selatan Kota palopo itu mengalami kemajuan apa tidak. Pendapatan perkapita, yaitu banyaknya pendapatan rata-rata penduduk dalam suatu masyarakat.

Pemerintahan yang ada di Kecamatan Wara Selatan Kota Palopo, dalam meningkatkan kesejahteraan penduduknya menyiapkan secara khusus dengan mengadakan pembangunan dari berbagai sektor. Hasil yang diharapkan dari pembangunan itu akan meningkatkan hasil produksi yang berupa barang dan jasa yang memiliki kualitas dan mempunyai jumlah yang banyak. Dari pembangunan itu, diharapkan adanya peningkatan pada pendapatan nasional yang akan menjadi cikal bakal peningkatan pendapatan perkapita penduduknya. Jadi, jika ada pernyataan apakah tingginya pendapatan perkapita suatu masyarakat menjadi tolak ukur kemakmuran penduduknya? Jawabannya belum tentu bisa dijadikan tolak ukur, kenapa tidak bisa dijadikan tolak ukur? Hal ini dikarenakan tingginya pendapatan perkapita nasional hanya dihasilkan oleh sebagian kecil penduduk pada suatu masyarakat. Permasalahan yang terpenting terletak pada distribusi pada pendapatan nasional perkapita itu sendiri, jadi bila ada sebagian penduduk pada suatu masyarakat memiliki pendapatan yang cukup tinggi, maka kemakmuran penduduk suatu masyarakat bisa dijadiakan tolak ukur pendapatan perkapita.

\section{BAHAN DAN METODE}

Jenis data yang digunakan dalam kegiatan penelitian ini adalah data kualitatif dan kuantitatif, sumber datanya yaitu data primer dan sekunder. Populasi sekaligus sebagai sampel dalam penelitian ini adalah semua permintaan 9 kebutuhan pokok masyarakat di Kecamatan Wara Selatan Kota Palopo.

Dalam penelitian ini, data yang digunakan keseluruhan merupakan data sekunder yang diperoleh secara langsung dari instansi terkait. Data-data tersebut dikumpulkan dengan cara wawancara Tanya langsung mengumpulkan data, 
mencatat dan mengkopi dokumen yang ada dalam instansi terkait.

Metode analisis data yang digunakan dalam penelitian ini adalah regresi sederhana sebagai berikut:

$\mathrm{Y}=\mathrm{a}+\mathrm{bX}$

Dimana :

$\mathrm{Y}=$ Pendapatan Perkapita

$\mathrm{X}=$ Permintaan Kebutuhan Pokok

$\mathrm{a}=$ konstanta

$\mathrm{b}=$ Slop dari Persamaan Regresi

\section{HASIL DAN PENJELASAN}

Penelitian ini diakukan dengan mengambil data time series dari BPS dan Badan Pengadaan Pelaksanaan Penyuluhan Kota Palopo yaitu berupa data Pendapatan Perkapita dan Permintaan Kebutuhan Pokok (Tingkat Konsumsi) dari tahun 2011 sampai tahun 2015.

\section{Mean dan Standar Deviasi Variabel}

Jenis penelitian merupakan penelitian penjelasan (explanatory research), yang mencoba untuk menjelaskan hubungan kausal (sebab-akibat) antar variable Independen (variabel bebas ) yaitu pendapatan perkapita, terhadap variabel Dependen (variabel terikat) yaitu kebutuhan pokok masyarakat di Kecamatan Wara Selatan Kota Palopo. Untuk memperoleh gambaran hubungan kausal-efek antar variabel yang diteliti digunakan bantuan program SPSS Versi 16.

\section{Analisis Data \\ Deskripsi Data}

Berdasarkaan hasil analisis deskripsi statistik, maka berikut akan disajikan karasteristik pendapatan perkapita dan permintaan kebutuhan pokok di Kecamatan Wara Selatan Kota Palopo dari tahun 2011-2015 yang meliputi jumlah sampel (N), rata-rata sampel (mean), niai maksimum, nilai minimum, serta standar deviasi untuk masing-masing variabel.

\section{Descriptive Statistics}

\begin{tabular}{|l|c|r|r|r|r|}
\hline & N & \multicolumn{1}{|c|}{ Minimum } & \multicolumn{1}{c|}{ Maximum } & \multicolumn{1}{c|}{ Mean } & \multicolumn{1}{c|}{ Std. Deviation } \\
\hline PendapatanPerkapitaY & 5 & 5145640.000 & 9596790.000 & 7309823.400 & 1845765.40333 \\
PermintaanKebutuhanPokok & 5 & 881.20 & 884.60 & 883.200 & 1370.004 \\
X & 5 & & & & \\
Valid N (listwise) & & & & \\
\hline
\end{tabular}

Dari data di atas dapat diketahui bahwa jumlah data yang digunakan data penelitian ini sebanyak 5 sampel. Berdasarkan hasil perhitungan selama periode pengamatan nampak bahwa pendapatan perkapita (Minimum) adalah 5145640.00 dan nilai tinggi (Maximum) 9596790.00. dari data diatas dapat dilihat bahwa

pendapatan perkapita secara rata-rata mengalami perubahan positif dengan rata-rata nilai sebesar 7309823.4. hal ini menunjukkan bahwa secara umum pendapatan perkapita yang menjadi sampel dalam penelitian ini mengalami peningkatan. Standar deviasi pendapatan perkapita yaitu sebesar 
1845764.40. Permintaan kebutuhan pokok (minimum) adalah 881.20 dan nilai tertinggi (maximum) 884.60. Dari data diatas dapat dilihat bahwa permintaan kebutuhan pokok secara ratarata mengalami perubahan positif dengan nilai sebesar 883.32 . Hal ini menunjukkan bahwa secara umum permintaan kebutuhan pokok mengalami peningkatan. Standar deviasi permintaan kebutuhan pokok yaitu sebesar 1,37.

\section{Uji Asumsi Klasik (Normalitas dan Multikolinieritas)}

\section{Uji Normalitas Data}

Screening terhadap normalitas data merupakan langkah awa yang harus dilakukan untuk setiap jenis analisis Multivariate.

Adapun hasil uji Normalitas data sebagai berikut :

Hasil Uji Normalitas untuk variable pendapatan perkapita dan permintaan kebutuhan pokok one-sampel kolmogorov smirnov Test

\begin{tabular}{|l|cr|}
\hline & \multicolumn{2}{|c|}{$\begin{array}{c}\text { Standar dizid } \\
\text { Residensual }\end{array}$} \\
\hline $\mathrm{N}$ & \multicolumn{2}{|c|}{5} \\
Normal Parameters ${ }^{\mathrm{a}, \mathrm{b}}$ & .0000000 \\
Mean & .86602540 \\
Std.Deviaton & 7 & .22 \\
Most Extreme Differences & & .22 \\
Absolute & 7 & - \\
Positive & .217 & \\
Negative & 9 & .50 \\
Kolmogorov - Smirnov Z \\
A syam. Sig. (2 tailed)
\end{tabular}

diketahui bahwa nilai signifikasi untuk pendapatan perkapita dan permintaan kebutuhan pokok yang sebelumnya telah di standarisasi adalah sebesar 0,959 . Karena nilai signifikansi lebih besar dari 0,05, maka disimpulkan bahwa pendapatan perkapita dan permintaan kebutuhan pokok berdistribusi normal.

\section{Uji Multikolinieritas}

Menurut Priyatno (2008:39) mutikolinieritas digunakan untuk mengetahui ada atau tidaknya penyimpangan asumsi klasik multikolinieritas, yaitu adanya hubungan linear antara variabel independen dengan dalam model regresi (model persamaan regresi). Dari pengujian multikolinieritas, di peroleh hasil sebagai berikut :

Dari hasil uji normalitas data pada table diatas pada kolom kolmogorov - smirnov 


\section{Hasil Uji Multikolinieritas Untuk Variabel \\ Permintaan Kebutuhan Pokok}

\section{Coefficients $^{\mathrm{a}}$}

\begin{tabular}{|c|c|c|c|c|c|c|c|}
\hline \multirow[b]{2}{*}{ Model } & \multicolumn{2}{|c|}{$\begin{array}{c}\text { Unstandardized } \\
\text { Coefficients }\end{array}$} & \multirow{2}{*}{$\begin{array}{c}\begin{array}{c}\text { Standardized } \\
\text { Coefficients }\end{array} \\
\text { Beta }\end{array}$} & \multirow[b]{2}{*}{$\mathrm{T}$} & \multirow[t]{2}{*}{ Sig. } & \multicolumn{2}{|c|}{ Colenearity Statistic } \\
\hline & B & Std. Error & & & & Tolerances & VIF \\
\hline 1. Constant & 878.418 & 1.377 & & 637.870 & .000 & & \\
\hline $\begin{array}{l}\text { Pendapatan } \\
\text { Perkapita }\end{array}$ & $\begin{array}{r}6.706 \mathrm{E} .00 \\
7\end{array}$ & .000 & .903 & 3.649 & .036 & 1.000 & 1.000 \\
\hline
\end{tabular}

Dependent Variable: Permintaan

Kebutuhan Pokok

Dari hasil diatas dapat diketahui nilai variabel pendapatan perkapita (1.000), adalah lebih kecil dari 5, hingga bisa diduga bahwa antar variabel independen tidak terjadi persoalan multikolinieritas.

\section{Penentuan Persamaan Regresi}

Berdasarkan hasil perhitungan sebagaimana terlihat pada gambar persamaan regresi sebagai berikut :

\section{Hasil Persamaan Regresi}

\section{Koefficienci $^{\mathrm{a}}$}

\begin{tabular}{|c|c|c|c|c|c|c|}
\hline \multirow{2}{*}{\multicolumn{2}{|c|}{ Model }} & \multicolumn{2}{|c|}{$\begin{array}{c}\text { Unstandardized } \\
\text { Coefficients }\end{array}$} & \multirow{2}{*}{$\begin{array}{c}\begin{array}{c}\text { Standardized } \\
\text { Coefficients }\end{array} \\
\text { Beta }\end{array}$} & \multirow[b]{2}{*}{$\mathrm{T}$} & \multirow[b]{2}{*}{ Sig. } \\
\hline & & B & $\begin{array}{l}\text { Std. } \\
\text { Error }\end{array}$ & & & \\
\hline 1 & (Constant) & 878.418 & 1.377 & & 637.870 & .000 \\
\hline & $\begin{array}{l}\text { Pendapatan } \\
\text { Perkapita }\end{array}$ & 6.706Е.007 & .000 & .903 & 3.649 & .036 \\
\hline
\end{tabular}

a. Dependent Variable: Permintaan kebutuhan pokok

Dari table diatas dapat diperoleh nilai persamaan regresi yaitu $\mathrm{Y}=878,418+0,903$ pendapatan perkapita.

$\mathrm{b}=$

Dimana masing-masing regresi tersebut mempunyai arti sebagai berikut :

$\mathrm{b}_{\mathrm{o}}=878,418$

Mempunyai arti bahwa jika pendapatan perkapita = 0 maka pendapatan daerah di Kecamatan Wara
Selatan Kota Palopo mengalami peningkatan sebesar 878,418

0,903 pendapatan perkapita

Variabel pendapatan perkapita dengan koefisien regresi sebesar 0,903, mempunyai arti bahwa jika pendapatan perkapita naik sebesar satu satuan, maka permintaan kebutuhan pokok di 
Kecamatan Wara Selatan Kota Palopo akan naik sebesar 0,903.

\section{Koefisien Determinasi/Adjusted R Square}

Analisis ini digunakan untuk mengetahui besarnya broporsi seimbang pengaruh variabelvariabel yang terdiri dari variabel pendapatan perkapita terhadap permintaan kebutuhan pokok di Kecamatan Wara Selatan Kota palopo. Berdasarkan hasil perhitungan pada gambar berikut diketahui :

\section{Tabel Koefisien Determinasi/Adjusted R Square}

\section{Mode C Summary}

\begin{tabular}{|c|c|c|r|r|}
\hline $\begin{array}{c}\text { Mod } \\
\text { el }\end{array}$ & R & $\begin{array}{c}\text { R } \\
\text { Square }\end{array}$ & $\begin{array}{c}\text { Adjusted R } \\
\text { Square }\end{array}$ & $\begin{array}{c}\text { Std. Error of } \\
\text { the Estimate }\end{array}$ \\
\hline 1 & $.903^{\mathrm{a}}$ & .816 & .755 & .67839 \\
\hline
\end{tabular}

Adjusted R Square sebesar 0,755 artinya bahwa variasi perubahan variabel terikat permintaan kebutuhan pokok di Kecamatan Wara Selatan Kota Palopo sebesar 75,5 \% di sebabkan oleh variabel bebas yaitu pendapatan perkapita. Sedangkan sisahnya sebesar 24,5\% disebabkan oleh variabel lain yang tidak teridentifikasi ke dalam model.

\section{Pengujian Secara Persial Variabel Pendapatan Perkapita}

Berdasarkan pada tabel persamaan regresi maka pengujian secara persial (Uji-t) dapat dilakukan sebagai berikut :

Penyusunan hipotesis yaitu :

1. $\mathrm{H}_{0}: \mathrm{B}_{1}=0$, variabel pendapatan perkapita tidak berpengaruh terhadap permintaan kebutuhan pokok di Kecamatan Wara Selatan Kota Palopo.

$\mathrm{H}_{\mathrm{a}}: \mathrm{B}_{1} \neq 0$ variabel pendapatan perkapita berpengaruh terhadap permintaan kebutuhan pokok di Kecamatan Wara Selatan Kota palopo.

2. Level of signifikan pada tingkat $\alpha=5 \%$

$\mathrm{T}_{\text {tabel }}$ pada derajat signifikan dengan pendekatan Uji hipotesis dua sisi dan derajat kebebasan $\mathrm{n}-\mathrm{k}$.

3. $\mathrm{T}_{\text {hitung }}<\mathrm{T}_{\text {tabel }}$ berarti $\mathrm{H}_{0}$ diterima dan $\mathrm{H}_{\mathrm{a}}$ ditolak $\mathrm{T}_{\text {hitung }}>\mathrm{T}_{\text {tabel }}$ berarti $\mathrm{H}_{\mathrm{a}}$ diterima dan $\mathrm{H}_{0}$ tolak

Dari hasil perhitungan diketahui bahwa variabel pendapatan perkapita menghasilkan nilai $\mathrm{t}_{\text {hitung }}=3,649>\mathrm{t}_{\text {tabel }}=3,182$ atau tingkat signifikansebesar 0,036 lebih kecil jika dibandingkan dengan tingkat $\alpha=5 \%$

Dari hasil perhitungan tersebut yang nyata dan signifikan antara pendapatan perkapita terhadap oermintaab kebutuhan pokok di Kecamatan Wara Selatan Kota Palopo.

Pembahasan Hipotesis Penelitian Pengaruh Variabel Pendapatan Perkapita Secara Persial (Uji-t) Terhadap Permintaan Kebutuhan Pokok di Kecamatan Wara Selatan Kota Palopo

Berdasarkan hasil penelitian dengan pengujian secara persial (Uji-t) yang menunjukkan bahwa variabel pendapatan perkapita berpengaruh positif signifikan terhadap permintaan kebutuhan pokok di Kecamatan Wara Selatan Kota Palopo dengan Koefisiensi regresi sebesar 0,903, artinya dengan meningkatnya variabel pendapatan perkapita akan meningkat pada permintaan kebutuhan pokok di Kecamatan Wara Selatan Kota Palopo diikutu dengan perubahan peningkatan 
signifikan, ini dapat dilihat dari tingkat signifikanyaitu sebesar 0,036 .

Hasil penelitian ini sejalan dengan jurnal penelitian yang dilakukan oleh Wahyu Danil (2013) dengan judul pengaruh pendapatan terhadap tingkat komsumsi pada Pegawai Negeri Sipil di Kota Palopo. Dimana hasil penelitian yaitu terdapat pengaruh yang signifikan antara tingkat pendapatan terhadap konsumsi.

\section{SIMPULAN}

Berdasarkan pokok permasalahan, tujuan penelitian, hasil analisis dan pembahasannya, dapat ditemukan kesimpuan yaitu pendapatan perkapita berpengaruh positif signifikan tterhadap permintaan kebutuhan pokok masyarakat di Kecamatan Wara Selatan Kota Palopo dengan nilai signifikan sebesar 0,036 .

\section{DAFTAR PUSTAKA}

Anonim, http://omrisal . blogspot. Com/2012/02/ pengertian-gnp-nnp-nni-pi

Anonim, http://febrihidayatullah. Wardpress. Com/2012/04/24/ pengertian pendapatannasional

Anonim, http://wardayadi.wordpress.com/materi ajar-ajar/kelas-x/kebutuhan-manusia/ diunggah/29/11/2013.

Arsyad Lincolin. 2004. Ekonomi Pembangunan, Yogyakarta: Sekolah Tinggi Ilmu Ekonomi YKPN.

Danil Wahyu. 2013. Pengaruh Pendapatan Terhadap Tingkat Konsumsi Pada Pegawai Negeri Sipil Di Kantor Bupati Kabupaten bireuen. Jurnal, Ekonomika. Aceh: Universitas Almuslim Bireuen
Eeng Ahman. 2004. Ekonomi, Bandung: Grafindo Media Pratama.

Hanafie Rita. 2010. Pengantar Ekonomi Pertanian, Yogyakarta: Andi.

Lincolin Arsyad 2004. Ekonomi Pembangunan, Penerbit SekolahTinggi Ilmu Ekonomi Jakarta

Murni Asfia. 2006. Ekonomika, Bandung: PT Rafika Aditama.

Nanga Muana. 2005. Makro Ekonomi Teori Masalah Dan Kebijakan, Jakarta: PT Raja Grafindo Persada.

Raharja Pratama. 2008. Teori Ekonomi Makro, Jakarta: Fakultas Ekonomi Universitas Indonesia.

Sudiono Armand. 2001. Pemasaran Pertanian, Malang: Universitas Muhammadiyah.

Sukirno Sadono. 2001. Makro Ekonomi Teori Pengantar, Penerbit Falkultas Ekonomi Universitas Indonesia

Sukirno Sudono. 2010. Mikro Ekonomi Teori Pengantar, Jakarta: Rajawali Pers

Sugiyono. 2012. Metode Penelitian Kuantitatif Kualitatif, Bandung: Alfabeta.

Sugiyono : 2002. Statistick Untuk Penelitian, Bandung: CV Alfabeta.

Taringan Robinson. 2005. Ekonomi Regional, Jakarta: PT. Bumi Aksara. 